УДК 343.82; 341.645

\title{
CONDITIONS OF DETENTION IN THE CASE-LAW \\ OF THE ECTHR: MINIMUM CONDITIONS, PILOT JUDGMENTS AND EFFECTIVE REMEDIES ${ }^{1}$
}

\author{
Síofra O'Leary \\ European Court of Human Rights, \\ F-67075 Strasbourg Cedex, France \\ e-mail: Siofra.Oleary@echr.coe.int
}

The article deals with the current state of case-law of the European Court of Human Rights regarding conditions of detention. The author refers to the statistics on such cases showing that the Court has found numerous violations of Article 3 of the Convention due to the conditions in which prisoners were detained being found to be inhuman and degrading. In addition, many other cases have been concluded on the basis of friendly settlements or unilateral declarations. Attention is drawn to the landmark judgment in Muršić v. Croatia in which the ECHR has clarified both the Convention standards and the methodology to be applied when assessing prison overcrowding. In comparing the standards of the ECHR and the CPT, reasons are provided regarding why the Strasbourg Court did not adopt the CPT standards as the Convention minimum. The author then describes the important role of the pilot judgment procedure which has helped the ECtHR to handle a large number of applications relating to prison conditions and overcrowding. As regards Ukraine, apart from the overall assessment, the recent case of Sukachov v. Ukraine is presented in which the ECtHR recently stressed the existence of a widespread structural problem resulting from the malfunctioning of the Ukrainian penal system and indicated a series of measures to counter this structural problem. Finally, the author examines the effects of ECtHR case-law on prison overcrowding in EU law and the case-law of the CJEU.

Keywords: conditions of detention, pilot judgment procedure, human rights standards,caselaw of the European Court of Human Rights.

DOI: http://dx.doi.org/10.30970/vla.2020.70.049

\section{Introduction}

Article 3 of the European Convention of Human Rights (ECHR) provides that no one shall be subjected to torture or to inhuman or degrading treatment or punishment.

It is important to stress, as the Strasbourg Court has always done, the absolute character of this article and the fact that it enshrines one of the most fundamental values of democratic societies. What is at issue in Article 3 cases is human dignity itself.

As you know, the case-law of the European Court of Human Rights in relation to Article 3 of the Convention and prison conditions is both well-established and, sadly, extensive.

To date the Court has found approximately 1300 violations of Article 3 of the Convention due to conditions in which prisoners were detained being found to be inhuman and degrading. In addition, many other cases have been concluded on the basis of a friendly settlement or unilateral declaration.

\footnotetext{
${ }^{1}$ This article is based on a presentation at the 8th Forum on ECtHR case-law, Ivan Franko National University of Lviv, 22nd November 2019. The views expressed are purely personal to the author.

(C) Síofra O’Leary, 2020
} 
In some cases violations of both articles 3 and 8 ECHR have been found, the latter on account of, for example, a failure to fulfil positive obligations to provide suitable sanitary facilities [49] or recourse to strip-searching [42]. In many other cases an additional complaint will see articles 3 and 13 combined due to a lack of effective domestic remedies $[3 ; 54 ; 5]$.

When the Court examines the complaints in relation to prison conditions received from members of this population it may have to address a combination of several of the following -

- unhygienic condition of cells,

- ill-treatment by cellmates or prison officers,

- the personal space available to detainees in multi-occupancy cells and problems of prison overcrowding generally,

- recourse to solitary confinement,

- strip searching,

- video surveillance within a cell,

- repeat transfers between prisons and conditions when transferred $[3 ; 14 ; 54 ; 18$; $26 ; 53 ; 5]$.

On $31^{\text {st }}$ January 2018, there were over $1,229,000$ inmates in the penal institutions of the 44 Council of Europe States covered by the 2018 Council of Europe Space 1 report $[24]^{1}$.

This statistic translates, for the ECtHR, into approximately 12,000 pending applications raising issues relating to conditions of detention.

In around 9,300 cases that is the main or only issue:

- approximately 7,050 applications are pending but "frozen" in relation to Romania, with the Committee of Ministers supervising the execution of a pilot judgment I will mention in a moment;

- approximately 1,600 cases concern Russia.

Hungary, which until recently would have featured on such a Court list, no longer does so for reasons explained later.

As in the presentation for the Lviv Forum on which this article is based, I will concentrate on prison overcrowding and space requirements in multi-occupancy cells ${ }^{2}$, on the minimum conditions required, the need for effective remedies and on how the ECtHR has sought to combat systemic problems in some States with recourse to the pilot judgment procedure.

Having outlined the general picture on Article 3 ECHR case-law relating to prison conditions, I will then explain the state of the case-law in relation to Ukraine.

The gravity of some of the problems which detainees, States and the Court have been facing is well-illustrated by the data provided in the 2017 pilot judgment Rezmives and Others $v$. Romania. In that case the Court referred to:

\footnotetext{
${ }^{1}$ See also, as regards Member States of the European Union, the report by the European Parliament, "Prison Conditions in the Member States: selected European standards and best practices" Policy Department C: Citizens' Rights and Constitutional Affairs, January 2017, and another report by the EU Fundamental Rights Agency, "Criminal Detention and alternatives", 2016.

${ }^{2}$ Note that, according to the ECtHR, different questions may arise under the Convention in the context of singleoccupancy accommodation, isolation or other similar detention regimes, or waiting rooms or similar spaces used for very short periods of time (such as police stations, psychiatric establishments, immigration detention facilities). These questions are not the subject of the present address which looks at prison overcrowding and conditions in multi-occupancy cells. See, in any event, for broader case-law on detainees, the ECtHR Factsheets on the following topics "Detention conditions and treatment of prisoners", "Detention and mental health" and "Prisoners' health-related rights".
} 
- a serious structural problem of overcrowding in that State which had been identified since 2012;

- a resulting influx of applications to the Court;

- an occupancy rate for all Romanian custodial facilities which varied between 149 and $154 \%$;

- the fact that the vast majority of recent judgments concerning Romania had involved applicants serving sentences in living space of less than 3 and sometimes less than 2 sq. $\mathrm{m}$.

\section{What standard and methodology does the ECtHR apply?}

In its 2016 judgment in Muršić v. Croatia, the Grand Chamber, after reviewing its existing case-law, clarified the Convention standards for the assessment of prison overcrowding $[17 ; 37 ; 33 ; 3 ; 51 ; 29 ; 54]$.

- It confirmed that the minimum standard of personal space is $3 \mathrm{sq} . \mathrm{m}$. per detainee; a standard which applies equally to remand detainees and prisoners.

- It clarified how to calculate that minimum space, excluding in-cell sanitary facilities but including furniture.

- It indicated that personal space below this minimum gave rise to a strong presumption of a violation of Article 3 ECHR.

- To rebut that strong presumption respondent States must demonstrate the presence of three cumulative factors capable of adequately compensating for the lack of sufficient personal space. Those factors are:

- the fact that reductions in space below the minimum are short, occasional and minor;

- such reductions in space must be offset by sufficient freedom of movement and adequate activities outside the cell;

- and detention must be in an appropriate facility with no other aggravating factors when it comes to conditions of detention.

- The Court also clarified that personal space of between 3-4 sq. m. would constitute a weighty factor in its assessment of conditions of detention ${ }^{1}$. When assessing the latter, the Court looks at their cumulative effects [23, § 163].

- Personal space of over $4 \mathrm{sq}$. m. would not, of itself, give rise to a violation of Article 3 ECHR, but again the Court could find a violation depending on the other physical conditions of detention $[28, \S \S 136-141]^{2}$.

The Muršić case had been referred to the Grand Chamber pursuant to Article 43 in order to clarify the Convention standard and method of assessment. ${ }^{3}$

The majority in Muršić highlighted the difficulties of setting a clear-cut numerical standard for the purpose of evaluating prison conditions from the perspective of Article 3

\footnotetext{
${ }^{1}$ In such instances a violation of Article 3 will be found if the reduced space factor is coupled with other aspects of inappropriate physical conditions of detention related to, in particular, access to outdoor exercise, natural light or air, availability of ventilation, adequacy of room temperature, the possibility of using the toilet in private, and compliance with basic sanitary and hygienic requirements.

${ }^{2}$ In Muršić, one period of detention (27 days) in less than 3 sq.m. was considered not to qualify as short or minor such that the presumption of a violation of Article 3 ECHR had not been rebutted by the Government. For the majority, that presumption was rebutted as regards other shorter periods of detention during which the applicant had less than the 3 sq.m. minimum of personal space given their duration and given access to out-of-cell activities in a detention facility considered otherwise adequate.

${ }^{3}$ While some previous cases had proceeded on the basis of 3 sq. $\mathrm{m}$. as the bare minimum, in others 4 sq. $\mathrm{m}$. had sufficed to establish a violation. In addition, there was a lack of clarity regarding the application of the strong presumption criterion. See the case-law overview in the dissenting opinion of Judge Sicilianos attached to the chamber judgment in Muršić, cited above.
} 
[28, § 96-101]. For the reasons explained in the judgment, it set the minimum standard at 3 sq. $\mathrm{m}$. and sought to provide domestic authorities with guidelines regarding how to proceed.

7 judges dissented, rejecting that figure as the trigger for closer scrutiny under Article 3 and preferring the CPT standard of 4 sq. $\mathrm{m}$ per prisoner in multi-occupancy cells $^{1}$. In other words, for the dissenting judges, personal space of less than $3 \mathrm{sq} . \mathrm{m}$. constituted an automatic violation of Article 3 ECHR.

The Muršić minimum standard and methodology have been applied in numerous cases since 2016 [45; 10; $1 ; 9]$.

I will explain later in what context Court of Justice of the European Union, based in Luxembourg, has also adopted the minimum standards on conditions of detention developed by the Strasbourg court.

III. How do ECtHR v. CPT standards compare?

In Muršic the Grand Chamber reiterated that when deciding cases in this field it remains attentive to the standards of the Committee for the Prevention of Torture and Inhuman and Degrading Treatment or Punishment (CPT) and to the Contracting States' observance of them.

Clearly, States remain free to and are encouraged to follow those standards. As successive CPT President's have said, in this field the CPT draws the line between the acceptable or desirable and the unacceptable or undesirable.

However, there appear to be two main reasons why the Strasbourg Court did not adopt the CPT standard as the Convention minimum:

- On the one hand, under Article 3 the Court is under a duty to take into account all the relevant circumstances of a particular case, whereas other international institutions such as the CPT develop general standards in this area;

- On the other hand, the Court and the CPT perform different roles. The CPT engages in pre-emptive action aimed at prevention. The Court is responsible for the judicial application in individual cases of the absolute prohibition contained in Article 3 [28, § 112-113].

As explained below, when adopting legislation in response Article 46 measures indicated by the Court in conditions of detention judgments, several States have opted to go beyond the Muršić minimum. Thus, following pilot judgments, in Bulgaria the minimum standard has been set at 4 sq. $\mathrm{m}$. and in Italy at a more generous 5 sq.m.

IV. How has the ECtHR handled such a large number of applications relating to prison conditions and overcrowding?

The answer to this question is to be found in the pilot judgment procedure which has developed in Strasbourg since $2004^{2}$. A regulatory framework for this procedure has since been established in the Rules of Court.

\footnotetext{
${ }^{1}$ See the joint partly dissenting opinions of Judges Lazarova Trajkovska, De Gaetano and Grozev in Muršić, cited above, $\S 2$ and $\S 9$. According to the CPT, the minimum standard for personal living space in prison establishments is: $6 \mathrm{~m}^{2}$ of living space (plus sanitary facility) for a single-occupancy cell, or $4 \mathrm{~m}^{2}$ per prisoner (plus fully-partitioned sanitary facility) in a multiple-occupancy cell; moreover, the walls of the cell must be at least $2 \mathrm{~m}$ from each other, and the ceiling at least $2.5 \mathrm{~m}$ from the floor. These standards are, however, meant to be a bare minimum: the CPT encourages States parties, especially when building new prisons, to follow the desirable standards (at least $10 \mathrm{~m}^{2}$ for a cell hosting two prisoners, $14 \mathrm{~m}^{2}$ for a cell hosting three, and so on).

${ }^{2}$ In the first pilot judgment, Broniowski v. Poland [GC], no. 31443/96, ECHR 2004-V, the Court drew attention to two instruments which had been adopted by the Committee of Ministers of the Council of Europe on 12 May 2004. The first, a resolution on judgments revealing an underlying systemic problem, invited the Court:

"to identify in its judgments finding a violation of the Convention what it considers to be an underlying systemic problem and the source of that problem, in particular when it is likely to give rise to numerous applications [...]".
} 
In addition, even when the pilot procedure is not used, the Court indicates individual and general measures to respondent States pursuant to Article 46 ECHR when violations are found.

The pilot judgment procedure was developed to identify the structural problems underlying repetitive cases and with a view to imposing an obligation on the States in question to address those problems. Where the Court receives several applications that share a root cause, it can select one or more for priority treatment under the pilot procedure.

A pilot judgment thus seeks, inter alia, to:

- identify systemic or structural problems at national level, assisting High Contracting Parties in solving them by giving them clear guidance regarding the type of remedial measures needed;

- offer applicants the possibility of speedier redress;

- assist the Committee of Ministers in supervising the execution of judgments;

- protect the effectiveness of the Convention system by reducing the number of similar cases which may in themselves be complex but in relation to which the general principles applicable under the Convention are clear.

As the Court stated in 2015 in Varga and Others v. Hungary:

"an important aim of the pilot-judgment procedure is to induce the respondent State to resolve large numbers of individual cases arising from the same structural problem at the domestic level, thus implementing the principle of subsidiarity which underpins the Convention system. Indeed, the Court's task, as defined by Article 19, that is to "ensure the observance of the engagements undertaken by the High Contracting Parties in the Convention and the Protocols thereto", is not necessarily best achieved by repeating the same findings in a large series of cases" [54, § 96].

As the Grand Chamber indicated in its strike out decision in Burmych v. Ukraine (a case which of course followed on from a pilot judgment on Article 6 ECHR), a large number of repetitive cases and, in particular, a failure by States to seek to resolve systemic problems in their domestic systems, risk encumbering the Court and constitute a threat to the Convention system itself [7] ${ }^{1}$.

One key feature of the pilot judgment procedure is the possibility of adjourning, or "freezing," related cases for a period of time on the condition that the Government act promptly to adopt the national measures required to satisfy the judgment [41, Rule $61 \S 6]$.

In Torreggiani and Others v. Italy [51, § 101] and Rezmiveş and Others $v$. Romania $[40, \S 128]$ for example, pending applications (which had not been communicated) were adjourned.

The second, a recommendation on the improvement of domestic remedies, emphasised that States had a general obligation to solve the problems underlying the violations found and recommended the setting up of "effective remedies, in order to avoid repetitive cases being brought before the Court". On pilot judgments generally see L. Wildhaber, "Pilot Judgments in Cases of Structural or Systemic Problems on the National Level' in R. Wolfrum and U. Deutsch (eds.), The ECtHR Overwhelmed by Applications: Problems and Possible Solutions, Berlin, 2009, pp. 69-75, or A. Buyse, "The Pilot Judgment Procedure at the European Court of Human Rights: Possibilities and Challenges" (2009) Greek Law Journal.

${ }^{1}$ It should be stressed that that case involved Article 6 ECHR and the non-enforcement of domestic judgments and not Article 3 ECHR. Nevertheless, it also concerned more generally the consequences for the ECtHR of State failure to comply with the indications provided in a pilot judgment and, more generally, with State failure to act in accordance with their primary responsibility pursuant to the Convention. See also, in this regard, the Copenhagen Declaration, Article 8:

"affirming that the States Parties, in accordance with the principle of subsidiarity, have the primary responsibility to secure the rights and freedoms defined in the Convention and the Protocols thereto, and that in doing so they enjoy a margin of appreciation, subject to the supervisory jurisdiction of the Court." 
This does not always happen. In Ananyev v. Russia and Varga v. Hungary pending applications were not frozen ${ }^{1}$. Not adjourning cases can constitute a form of continued or additional pressure on the respondent State.

As indicated previously, in February 2011, the Court added a new rule to its Rules of Court codifying the developing pilot judgment procedure and establishing a clear regulatory framework in which it would operate [41, Rule 61] $]^{2}$.

The Court has thus far adopted pilot judgments addressing the question of prison overcrowding in respect of Bulgaria [29], Hungary [54; 50; 20;15; 13], Italy [51], Poland [37; 33] $]^{3}$, Romania [40; 16] and Russia ${ }^{4}$, In these cases it characterised prison overcrowding as a systemic problem arising out of chronic dysfunction in the domestic penal systems under review affecting and liable to affect a large number of people [51].

In some other cases, which are not strictly speaking pilot judgments, the Court has nevertheless provided indications, pursuant to Article $46 \mathrm{ECHR}$, regarding the need to improve conditions of detention with concrete suggestions regarding how this might be done. Leading judgments of this nature have been pronounced in relation to Belgium $\left[56^{5} ; 55 ; 48\right]$, Greece [43; 52; 2], Slovenia [25; 47], the Republic of Moldova [44] $]^{6}$, and, most recently, France [21].

\section{$\mathrm{V}$. What should happen after a pilot judgment?}

The pilot judgments in relation to Italy, Bulgaria, Hungary and Romania provide an illustration of what should happen thereafter.

In these judgments, under Article 46 ECHR, the Court will have held that the domestic authorities should promptly put in place an effective remedy or a combination of remedies, both preventive and compensatory, to guarantee genuinely effective redress for violations of the Convention originating in overcrowding. A compensatory remedy will not be sufficient redress in relation to persons who remain in detention $[51 ; 29 ; 54]$.

In Stella and Others v. Italy (2014) [46], the Court examined the measures adopted by Italy following the pilot judgment in Torreggiani:

\footnotetext{
${ }^{1}$ See Ananyev and Others [3, § 236], and Varga and Others [54, § 128]:

"Having regard to the fundamental nature of the right protected by Article 3 of the Convention and the importance and urgency of complaints about inhuman or degrading treatment, the Court does not consider it appropriate at this stage to adjourn the examination of similar cases pending the implementation of the relevant measures by the respondent State. Rather, the Court finds that continuing to process all conditions of detention cases in the usual manner will remind the respondent State on a regular basis of its obligation under the Convention and in particular resulting from this judgment ..."

${ }^{2}$ A distinction can be drawn between pilot judgments in the strict sense - those which specify, in accordance with Rule $61 \S 3$ of the Rules of Court, in the operative part of the judgment the nature of the systemic problem and the type of remedial measures that the State concerned must adopt and those which merely mention the systemic nature of the problem in the body of the Court's reasoning without more.

${ }^{3}$ In 2008 the Polish Constitutional Court had found that detention facilities in Poland suffered from a systemic problem of overcrowding which was of such a serious nature as to constitute inhuman and degrading treatment. At the time of the judgment in Orchowski, 160 applications were pending in which inadequate prison conditions were at issue.

${ }^{4}$ See Ananyev and Others [3], which in annex lists the 88 judgments in which the Court had previously found Articles 3 and/or 13 ECHR violations as regards conditions of detention. At that time, a further 250 cases were pending. This was the second pilot judgment against Russia but the first concerning conditions of detention, in that case, as regards detainees pending trial.

${ }^{5}$ Although it should be noted that this case related to detention in a prison psychiatric wing.

${ }^{6}$ See, however, the recent decision in Draniceru v. the Republic of Moldova (dec.) [11], in which the Court examined, and deemed as effective, domestic remedies adopted by legislation in 2017 and 2018 and which had entered into force on 1 January 2019. The effectiveness of the remedy meant that there was an immediate obligation on applicants to exhaust it, with the proviso that anyone with an application pending at the date of the decision was allowed an additional four months to use it. Mention should also be made of some Estonian cases - Nikitin and Others v. Estonia [31], and the pending applications in Karp v. Estonia, no. 57738/16 and Savva v. Estonia, no. 60178/16.
} 
- A new preventive remedy had been adopted which specified that the decisions taken by the judge responsible for the execution of sentences on prisoners' complaints concerning the prison administration were binding on the relevant administrative authorities. The latter were obliged to comply within a deadline set by the judge, which, in principle, satisfied the criterion that judicial proceedings be expeditious, failing which enforcement proceedings could be initiated;

- Crucially, the respondent State had put in place a series of substantive measures intended to resolve the structural problem of overcrowding in prisons. It had sought to make greater use of alternatives to detention; reduce sentences laid down for minor offences; introduced organisational changes allowing prisoners more time outside their cells and carried out works renovating existing prison buildings and constructing new premises.

- As regards the new Italian compensatory remedy, it provided for either a reduction in sentence or per diem compensation for each day spent in conditions considered contrary to the Convention.

Since the Court in Stella considered the new remedies to be effective, applicants were required to use them in order to obtain acknowledgment of any violation and, where appropriate, adequate compensation.

As regards Bulgaria, a programme of prison refurbishment was undertaken and legislation was adopted in 2017. It specified 4 sq. $\mathrm{m}$. as the minimum required living space, introduced more flexibility in the allocation of prisoners to correctional facilities and in the imposition and modification of prison regimes, widened the scope for conditional release and introduced preventive and compensatory mechanisms in relation to poor conditions of detention. The Court deemed these mechanisms to be effective in its 2017 decision in the case of Atanasov and Apostolov v. Bulgaria [4]1․

As regards Hungary, when the Court handed down its pilot judgment in Varga $v$. Hungary in 2015, 450 prima facie meritorious applications were pending against that State. That number grew to some 8000 cases. Given these numbers, the domestic response to the Varga pilot judgment was important.

In November 2017, in Domján v. Hungary, the Court held that legislation adopted in 2016 which provided for a combination of remedies, both preventive and compensatory in nature, guaranteed in principle genuine redress for Convention violations originating in prison overcrowding and other unsuitable conditions of detention in Hungary:

- Complaints could be submitted to prison governors who had to act on them swiftly;

- Judicial review was available as regards the prison governor's decision;

- The provisions on per diem compensation due to unsuitable conditions of detention were considered not unreasonable, having regard to economic realities.

Once again, the effectiveness of the remedy meant, in essence, that applicants had to exhaust it before coming to the Court. However, in Domján the Court did indicate - and this is important in relation to all apparently effective remedies adopted in response to pilot judgments and Article 46 indications - that it would review its position on the effectiveness of the new Hungarian remedy if, in practice, it was demonstrated that detainees were being refused relocation and/or compensation on formalistic grounds, that the domestic proceedings were excessively long or that domestic case-law was not in compliance with the requirements of the Convention. This type of "wait and see" policy in relation to a new remedy, initially deemed effective, is not unusual and not restricted to prison condition cases.

\footnotetext{
${ }^{1}$ Note that, since the remedy in question had been put in place in response to a pilot judgment, the Court considered that it could be taken into account even though it was not yet in force when the applications were lodged.
} 
As regards Romania, in the pilot judgment in Rezmives the Court indicated that, pending the adoption by the domestic authorities of the necessary measures at national level, it would adjourn the examination of any uncommunicated applications where the sole or main complaint concerns overcrowding and poor detention conditions in prisons and police cells in Romania. That process is now under the supervision of the Committee of Ministers. In that judgment, the Court went into considerable detail regarding the general measures required to reduce prison overcrowding in Romania and deal with material conditions of detention.

In these pilot judgment cases the Court tends to stress that it is not for it to indicate to States how to run their penal and prison systems [51, § 95; 3; § 194]. However, with reference to recommendations from the Committee of Ministers [39], the CPT and the White Paper on prison overcrowding [12], it can engage in quite detailed examination of what may need to be done. Article 46 indications can extend to recommending greater recourse to non-custodial measures and minimising recourse to pre-trial detention $[54 ; \S$ 104]. Article 46 indications which are regarded as particularly intrusive when it comes to domestic penal systems have attracted criticism, however, both from within the Court itself and outwith ${ }^{1}$.

\section{The situation in Ukraine}

The first violations of Article 3 in relation to prison conditions in Ukraine were handed down in $2005[30]^{2}$. Since then almost 50 final judgments against Ukraine have found similar violations on account of the inadequate conditions of the applicants' detention.

Since $1^{\text {st }}$ September 1997, when the European Convention for the Prevention of Torture and Inhuman and Degrading Treatment or Punishment entered into force in respect of Ukraine, CPT delegations have visited various detention facilities in Ukraine. The recommendations of the CPT have centred on the need to remedy overcrowding, the refurbishment of older prisons and provision of proper sanitary facilities as well as the need to ensure that prisoners have access to outdoor exercise space and facilities.

At a number of its meetings the Committee of Ministers has considered, pursuant to Article $46 \S 2$ ECHR, measures adopted by the Government of Ukraine with a view to complying with the Court's judgments in this field.

During the 1288th meeting held on 6-7 June 2017, the CM examined the Nevmerzhitsky, Yakovenko, Logvinenko, Isayev and Melnik group of cases which concern conditions of detention and medical assistance in pre-trial detention facilities. It noted the Ukrainian authorities' commitment to adopting comprehensive measures to resolve the complex issues raised by these judgments and that the important legislative and institutional reforms were underway in Ukraine. In particular, a draft law was then being elaborated aimed at introducing both preventive and compensatory remedies. However, the Committee of Ministers decided to change the classification indicator for all of these groups from a complex problem to a structural one, given that it is increasingly clear from the Court's judgments that the issues raised are structural in nature.

In December 2017, the case of Sukachov v. Ukraine was communicated. The applicant in that case complained under Article 3 about the conditions of his pre-trial detention in the Dnipro SIZO where he was held for 18 months. The judgment in Sukachov was handed down in early 2020 [32]. A violation of Articles 3 and 13 was found unanimously and the Court considered it appropriate to apply the pilot-judgment procedure in that case, the violations identified having been found fourteen years after

\footnotetext{
${ }^{1}$ See the concurring opinion of Judge Wojtyczek in Rezmiveș [40].

${ }^{2}$ Which concerned SIZO no. 1 of the Kyiv Region.
} 
the Court's first judgment concerning conditions of detentions in Ukraine. In this respect, the Court stressed the existence of a "widespread structural problem resulting from a malfunctioning of the Ukrainian penal system and insufficient safeguards against treatment proscribed by Article 3" [32, § 137].

The Court indicated a series of measures to counter this structural problem, namely reducing the number of detainees by more frequent use of non-custodial measures and by minimising the recourse to pre-trial detention, prosecutors and judges are encouraged to use alternatives to detention as widely as possible and the renovation of detention facilities [32, $\S \S 145-152]$. As concerns effective remedies, the Court encouraged Ukraine to create an independent authority designed to supervise detention facilities and to compensate inadequate conditions of detention by reducing the sentence of the prisoners concerned or by providing monetary compensation [32, $\S \S 153-160]$. It should be noted that the Court did not consider it appropriate to adjourn the examination of similar pending cases $[32, \S 161]$, which will have to be examined individually.

In this respect, there are at present 32 cases pending before the Court in which the sole complaint against Ukraine relation to the material conditions of pre-trial detention: overcrowding and other conditions such as poor light, ventilation, food, sleeping conditions and lack of access to a shower and sanitary facilities. In 81 other cases, complaints relating to conditions of detention under Article 3 ECHR combine with other complaints about lack of medical assistance or complaints under Articles 5 and 6 ECHR. A significant number of complaints (25) were received in 2019 alone in relation to the conditions in Kyiv and Dnipro Pre-trial Detention Facilities.

I understand that the reforms to which reference was made by the Committee of Ministers include the Concept of Reform Development of the Prison System in Ukraine, which was adopted in 2017 and sets out the general principles underlying the reform and functioning of the prison system. A series of complex and costly reforms are outlined in that report, ranging from repairing existing facilities, constructing new ones and bringing conditions of detention in line with European Prison Rules. The Committee of Ministers also referred to a draft law on preventive and compensatory remedies for convicted persons and detainees who have suffered treatment contrary to Article 3 was submitted to Parliament in 2016. It provided for preventive and compensatory remedies and introduces the institution of the "post-sentencing judge" who deals with applications from detainees seeking such remedies. However, as indicated in the Sukachov judgment, it would appear from information on the Ukrainian Parliament website that this draft law was withdrawn in August 2019.

\section{The effects of ECtHR case-law on prison overcrowding in EU law}

Readers will know that the origins of the EU were predominantly economic. As such, it may come as a surprise, even to judges and lawyers in EU Member States and specialised in a wide variety of EU legal questions to learn that the question of prison conditions now appears with relative frequency on the docket of the EU court in Luxembourg.

The reason for this can be found of course in the EU Area of Freedom, Security of Justice (AFSJ), first developed as a separate pillar in the Treaty of Amsterdam and since fully integrated by the Treaty of Lisbon in 2009.

The EU and the AFSJ, in particular, operate on the basis of a principle of mutual recognition or trust. In the words of the CJEU in Opinion 2/13 on accession to the ECHR:

"Th[e EU] legal structure is based on the fundamental premise that each Member State shares with all the other Member States, and recognises that they share with it, a set of common values on which the EU is founded, as stated in Article 2 TEU. That premise implies and justifies the existence of mutual trust between the Member States that those 
values will be recognised and, therefore, that the law of the EU that implements them will be respected" [36, $\S 168]$.

Action by the EU in the field of judicial cooperation in criminal matters may be affected by detention conditions across EU Member States since, without mutual confidence in the area of detention, EU mutual recognition instruments which have a bearing on imprisonment will not work properly. The EU Framework Decision on the European Arrest Warrant (EAW), for example, proceeds on the basis of this system of trust between the authorities of the State which issues a warrant (the issuing State) and those of the State which is intended to execute it (the executing State) ${ }^{1}$.

However, the EAW Framework Decision also states that: "it shall not have the effect of modifying the obligation to respect fundamental rights and fundamental legal principles as enshrined in Article 6 [TEU]'2.

In 2016, in a landmark case called Aranyosi and Căldăraru, a German court asked the CJEU whether the possibility or probability of degrading detention conditions, resulting from a systemic deficiency in the prisons of the issuing Member State, permit the executing judicial authorities in another Member State to refuse to surrender the person subject to the EAW [22]? The EAWs in question had been issued by authorities in Hungary and Romania.

In that case, the CJEU held that where the authority responsible for the execution of a warrant has in its possession evidence of a real risk of inhuman or degrading treatment of persons detained in the Member State where the warrant was issued, that authority must further assess that risk before deciding on the surrender of the individual concerned. That assessment should cover whether the risk derives from the general detention conditions in the Member State concerned (which risk cannot, in itself, lead to the execution of the warrant being refused) and whether there are substantial grounds for believing that the individual concerned will in fact be exposed to such a risk because of the conditions in which it is envisaged that he/she will be detained.

The CJEU's first engagement with conditions of detention in 2016 was followed by another preliminary ruling in 2018 in $M L v$. Generalstaatsanwaltschaft Bremen in relation to the execution of an EAW in order for the person subject to it to serve a custodial sentence in Hungary [27]. In that case the German executing authority had sought additional information from the issuing authorities in Hungary regarding where the sentence would be served. The question referred to the CJEU was whether, in cases of systemic or generalised deficiencies in the detention conditions in the prisons of the issuing Member State, the risk of inhuman and degrading treatment could be excluded merely because of the availability in the issuing Member State of a legal remedy enabling the person subject to the warrant to challenge the conditions of his detention. In addition, the CJEU had to address whether the risk assessment had to look at the conditions of detention in all the prisons in which the person concerned could potentially be detained

\footnotetext{
${ }^{1}$ See Council Framework Decision 2002/584/JHA of 13 June 2002 on the European arrest warrant and the surrender procedures between Member States [35, p. 1-20]. Other EU mutual recognition instruments of relevance would be Council Framework Decision 2008/909/JHA of 27 November 2008 on the application of the principle of mutual recognition to judgments in criminal matters imposing custodial sentences or measures involving deprivation of liberty for the purpose of their enforcement in the EU; Council Framework Decision 2008/947/JHA of 27 November 2008 on the application of the principle of mutual recognition to judgments and probation decisions with a view to the supervision of probation measures and alternative sanctions; Council Framework Decision 2009/829/JHA of 23 October 2009 on the application, between Member States of the EU, of the principle of mutual recognition to decisions on supervision measures as an alternative to provisional detention.

${ }^{2}$ See Article 1(3) of Framework Decision 2002/584/JHA.
} 
or those in which he is likely to be detained for most of the time and the role played by any assurances provided by authorities in the issuing Member State.

In $M L$ the CJEU did not itself address whether there were systemic deficiencies in prison conditions in Hungary. It proceeded instead on the basis presented by the referring court that there were. It held that the existence of effective legal remedies for detainees in the issuing State did not absolve the executing authority from the obligation to undertake an individual assessment of the situation of each person concerned. Citing the ECtHR decision in Domján v. Hungary, the Luxembourg court pointed out that the effectiveness of the remedy meant, on the one hand, that applicants had to exhaust it and in any event, the ECtHR had reserved the right to re-examine the effectiveness of the newly established remedy in the light of its application in practice [27, $\S 72-76]$. In addition, the Luxembourg court stipulated that the executing judicial authority is required to assess only the conditions of detention in the prisons in which the person is likely to be detained. The assessment need solely relate to the actual and precise conditions of detention of the person concerned and account may be taken of an assurance issued by an authority in the issuing State that the individual concerned will not be subject to inhuman or degrading treatment.

This dialogue between the two European courts regarding the interpretation of Article 3 ECHR and Article 4 of the EU Charter in the context of conditions of detention looks set to continue.

In October 2018, the CJEU was asked whether, when an EAW request is being executed, the authorities in the executing State are required to ensure that the minimum standards established by the Strasbourg court in Muršic are observed in the State issuing the warrant and in which the person the subject of the warrant will be imprisoned or whether the EU requires higher standards such as those, for example, of the CPT (see above) [8]. It held that as regards, in particular, the personal space available to each detainee, the executing judicial authority must, in the absence, currently, of minimum standards in that respect under EU law, take account of the minimum requirements under Article 3 of the ECHR, as interpreted by the European Court of Human Rights. In calculating that available space, the area occupied by sanitary facilities should not be taken into account, while the calculation should include space occupied by furniture. Detainees must, however, still have the possibility of moving around normally within the cell ${ }^{1}$.

\section{Conclusions}

The repetitive nature of the Strasbourg case-law just described should not blind us to the fundamental character of the right which this Article 3 case-law seeks to protect.

In Samaras and others v. Greece, for example, following a visit to one prison, the ombudsman of the Republic described the proportion of space to the number of detainees as being "absolutely intolerable", with some detainees not enjoying, when standing, even as much as $1 \mathrm{~m}^{2}$ of space $[43, \S 60]$. The CPT in its reports illustrate often in graphic detail what such prison life entails.

Added to this are the other aggravating factors which often characterise the life of detainees in such facilities - poor light and ventilation, the absence of adequate sanitary facilities, fewer beds than inmates, little or no access to outdoor space or activities, poor food and infestations of different kinds [16, §§ 173-178].

\footnotetext{
${ }^{1}$ As you may know, Article $53 \S 2$ of the EU Charter, which was given binding legal force by the EU Treaty of Lisbon in 2009, provides for a correspondence clause such that where EU Charter ECHR rights correspond, "the meaning and scope of those rights shall be the same as those laid down in the Convention". The explanations which accompany the Charter refer, moreover, to the case-law of the ECtHR [34,p. 17].
} 
The statistics, which this article has included, should not blind us either to the daily reality of what these cases entail.

I explained above when and why the Court has recourse to the pilot judgment procedure and the significant improvements which those judgments have sought to achieve at national level. Whether this occurs will depend on the measures adopted, applied and maintained by the States in question, which it falls to the Committee of Ministers to supervise.

In the 2018 Space 1 report published by the Council of Europe, in terms of prison density based on the number of inmates per 100 detention places, Greece, the Czech Republic, Portugal, Italy, France and Romania, to name but a few, all registered prison density figures above 100 , rising to 120.5 in the case of Romania.

In my own State, Ireland, which falls on the right side of the median in the Space 1 report, one NGO recently reported that one women-only facility was at $196 \%$ capacity. In some reports presented to a Council of Europe conference in 2019, one sees individual facilities in some States running at over $200 \%$.

When concluding my presentation at the Lviv Forum I wished the participants, who came from all walks of Ukrainian judicial and legal life, every success in their important work applying the Convention. As the ECtHR has repeatedly emphasised, the subsidiary nature of the protection mechanism put in place by the Convention system means that primary responsibility for compliance with Convention standards remains with the Member States and within the Member States with national judges. Across Council of Europe States there is plenty of work still to be done [38, pp. 6-7].

\section{Список використаних джерел}

1. Á.R. v. Hungary, no. 20440/15, 17 October 2017.

2. Al. K. v. Greece, no. 63542/11, 11 December 2014.

3. Ananyev and Others v. Russia, nos. 42525/07 and 60800/08, 10 January 2012.

4. Atanasov and Apostolov v. Bulgaria (dec.), nos. 65540/16 and 22368/17, 27 June 2017.

5. Bamouhammad v. Belgium, no. 47687/13, 17 November 2015.

6. Broniowski v. Poland [GC], no. 31443/96, ECHR 2004-V.

7. Burmych and Others v. Ukraine (striking out) [GC], nos. 46852/13 et al, 12 October 2017.

8. Case C-128/18 Criminal Proceedings against Dumitru-Tudor Dorobantu EU:C:2019:857.

9. Domján v. Hungary (dec.), no. 5433/17, decision of 14 November 2017.

10. Dorneanu v. Romania, no. 55089/13, 28 November 2017.

11. Draniceru v. the Republic of Moldova (dec.), no. 31975/15, decision of 12 February 2019.

12. White Paper on Prison Overcrowding / European Committee on Crime Problems (CDPC). - 2016.

13. Fehér v. Hungary, 69095/10, 2 July 2013.

14. Gjini v. Serbia, no. 1128/16, 15 January 2019.

15. Hagyó v. Hungary, 52624/10, 23 April 2013.

16. Iacov Stanciu v. Romania, no. 35972/05, 24 July 2012.

17. Idalov v. Russia [GC], no. 5826/03, 22 May 2012.

18. Ilaşcu and Others v. Moldova and Russia [GC], no. 48787/99, ECHR 2004-VII.

19. Ilgiz Khalikov v. Russia, no. 48724/15, 15 January 2019.

20. István Gábor Kovács v. Hungary, 15707/10, 17 January 2012.

21. J.M.B. and others v. France, no. 9671/15 (and others), 30 January 2020.

22. Joined Cases C-404/15 and C-659/15 PPU, EU:C:2016:198.

23. Khlaifia and Others v. Italy [GC], no. 16483/12, 15 December 2016.

24. Aebi M. F., Tiago M. M. Prison Populations, SPACE I - 2018. Council of Europe, Strasbourg. -20 December 2018. 
25. Mandić and Jović v. Slovenia, nos. 5774/10 and 5985/10, 20 October 2011.

26. Milka v. Poland, no. 14322/12, 15 September 2015.

27. ML v. Generalstaatsanwaltschaft Bremen, Case C-220/18 PPU, EU:C:2018:589.

28. Muršić v. Croatia [GC], no. 7334/13, 20 October 2016.

29. Neshkov and Others v. Bulgaria, nos. 36925/10, 21487/12, 72893/12, 73196/12, 77718/12 and 9717/13, 27 January 2015.

30. Nevmerzhitsky v. Ukraine, no. 54825/00, ECHR 2005-11.

31. Nikitin and Others v. Estonia, nos. 23226/16 and 6 others, 29 January 2019.

32. No. 14057/17, 30 January 2020.

33. Norbert Sikorski v. Poland, no. 17599/05, 22 October 2009.

34. OJ 2007 C 303.

35. OJ L 190, 18.7.2002.

36. Opinion 2/13, EU:C:2014:2454.

37. Orchowski v. Poland, no. 17885/04, 22 October 2009.

38. Prisons and Prisoners in Europe 2018: Key Findings of the SPACE I report.

39. Recommendation (99) 22 concerning prison overcrowding and prison population inflation / Committee of Ministers of the Council of Europe. - 30 September 1999.

40. Rezmives and Others v. Romania, nos. 61467/12 and 3 others, 25 April 2017.

41. Rules of Court / European Court of Human Rights, Council of Europe. - 1 August 2018.

42. S.J. v. Luxembourg, no. 34471/04, 4 March 2008.

43. Samaras and Others v. Greece, no. 11463/09, 28 February 2012.

44. Shishanov v. the Republic of Moldova, no. 11353/06, 15 September 2015.

45. Stănculeanu v. Romania, no. 26990/15, 9 January 2018.

46. Stella and Others v. Italy (dec.), nos. 49169/09, 54908/09, 55156/09, 16 September 2014.

47. Štrucl and Others v. Slovenia, nos. 5903/10, 6003/10 and 6544/10, 20 October 2011.

48. Sylla and Nollomont v. Belgium, nos. 37768/13 and 36467/14, 16 May 2017.

49. Szafrański v. Poland, no. 17249/12, 15 December 2015.

50. Szél v. Hungary, 30221/06, 7 June 2011.

51. Torreggiani and Others v. Italy, nos. 43517/09, 46882/09, 55400/09, 57875/09, 61535/09, 35315/10 and 37818/10, 8 January 2013.

52. Tzamalis and Others v. Greece, no. 15894/09, 4 December 2012

53. Van der Graaf v. the Netherlands (dec.), no. 8704/03, 1 June 2004.

54. Varga and Others v. Hungary, nos. 14097/12 and 5 others, 10 March 2015.

55. Vasilescu v. Belgium, no. 64682/12, 25 November 2014.

56. W.D. v. Belgium, no. 73548/13, 6 September 2016.

\section{References}

1. A.R. v. Hungary, no. 20440/15, 17 October 2017.

2. Al. K. v. Greece, no. 63542/11, 11 December 2014.

3. Ananyev and Others v. Russia, nos. 42525/07 and 60800/08, 10 January 2012.

4. Atanasov and Apostolov v. Bulgaria (dec.), nos. 65540/16 and 22368/17, 27 June 2017.

5. Bamouhammad v. Belgium, no. 47687/13, 17 November 2015.

6. Broniowski v. Poland [GC], no. 31443/96, ECHR 2004-V.

7. Burmych and Others v. Ukraine (striking out) [GC], nos. 46852/13 et al, 12 October 2017.

8. Case C-128/18 Criminal Proceedings against Dumitru-Tudor Dorobantu EU:C:2019:857.

9. Domján v. Hungary (dec.), no. 5433/17, decision of 14 November 2017.

10. Dorneanu v. Romania, no. 55089/13, 28 November 2017.

11. Draniceru v. the Republic of Moldova (dec.), no. 31975/15, decision of 12 February 2019.

12. White Paper on Prison Overcrowding. (2016). European Committee on Crime Problems (CDPC). 
13. Fehér v. Hungary, 69095/10, 2 July 2013.

14. Gjini v. Serbia, no. 1128/16, 15 January 2019.

15. Hagyó v. Hungary, 52624/10, 23 April 2013.

16. Iacov Stanciu v. Romania, no. 35972/05, 24 July 2012.

17. Idalov v. Russia [GC], no. 5826/03, 22 May 2012.

18. Ilaşcu and Others v. Moldova and Russia [GC], no. 48787/99, ECHR 2004-VII.

19. Ilgiz Khalikov v. Russia, no. 48724/15, 15 January 2019.

20. István Gábor Kovács v. Hungary, 15707/10, 17 January 2012.

21. J.M.B. and others v. France, no. 9671/15 (and others), 30 January 2020.

22. Joined Cases C-404/15 and C-659/15 PPU, EU:C:2016:198.

23. Khlaifia and Others v. Italy [GC], no. 16483/12, 15 December 2016.

24. Aebi, M. F., \& Tiago, M. M. (2018). Prison Populations, SPACE I - 2018. Council of Europe, Strasbourg.

25. Mandić and Jović v. Slovenia, nos. 5774/10 and 5985/10, 20 October 2011.

26. Milka v. Poland, no. 14322/12, 15 September 2015.

27. ML v. Generalstaatsanwaltschaft Bremen, Case C-220/18 PPU, EU:C:2018:589.

28. Muršić v. Croatia [GC], no. 7334/13, 20 October 2016.

29. Neshkov and Others v. Bulgaria, nos. 36925/10, 21487/12, 72893/12, 73196/12, 77718/12 and 9717/13, 27 January 2015.

30. Nevmerzhitsky v. Ukraine, no. 54825/00, ECHR 2005-11.

31. Nikitin and Others v. Estonia, nos. 23226/16 and 6 others, 29 January 2019.

32. No. 14057/17, 30 January 2020.

33. Norbert Sikorski v. Poland, no. 17599/05, 22 October 2009.

34. OJ 2007 C 303.

35. OJ L 190, 18.7.2002.

36. Opinion 2/13, EU:C:2014:2454.

37. Orchowski v. Poland, no. 17885/04, 22 October 2009.

38. Prisons and Prisoners in Europe 2018: Key Findings of the SPACE I report. (2019).

39. Recommendation (99) 22 concerning prison overcrowding and prison population inflation. (1999). Committee of Ministers of the Council of Europe.

40. Rezmiveș and Others v. Romania, nos. 61467/12 and 3 others, 25 April 2017.

41. Rules of Court. (2018). European Court of Human Rights, Council of Europe.

42. S.J. v. Luxembourg, no. 34471/04, 4 March 2008.

43. Samaras and Others v. Greece, no. 11463/09, 28 February 2012.

44. Shishanov v. the Republic of Moldova, no. 11353/06, 15 September 2015.

45. Stănculeanu v. Romania, no. 26990/15, 9 January 2018.

46. Stella and Others v. Italy (dec.), nos. 49169/09, 54908/09, 55156/09, 16 September 2014.

47. Strucl and Others v. Slovenia, nos. 5903/10, 6003/10 and 6544/10, 20 October 2011.

48. Sylla and Nollomont v. Belgium, nos. 37768/13 and 36467/14, 16 May 2017.

49. Szafrański v. Poland, no. 17249/12, 15 December 2015.

50. Szél v. Hungary, 30221/06, 7 June 2011.

51. Torreggiani and Others v. Italy, nos. 43517/09, 46882/09, 55400/09, 57875/09, 61535/09, 35315/10 and 37818/10, 8 January 2013.

52. Tzamalis and Others v. Greece, no. 15894/09, 4 December 2012

53. Van der Graaf v. the Netherlands (dec.), no. 8704/03, 1 June 2004.

54. Varga and Others v. Hungary, nos. 14097/12 and 5 others, 10 March 2015.

55. Vasilescu v. Belgium, no. 64682/12, 25 November 2014.

56. W.D. v. Belgium, no. 73548/13, 6 September 2016 


\title{
УМОВИ ТРИМАННЯ ПІД ВАРТОЮ ВІДПОВІДНО ДО ПРАКТИКИ ЄВРОПЕЙСЬКОГО СУДУ 3 ПРАВ ЛЮДИНИ: МІНІМАЛЬНІ УМОВИ, ПІЛОТНІ РІШЕННЯ ТА ЕФЕКТИВНІ ЗАСОБИ ЗАХИСТУ
}

\author{
Cioppa O’’ipi \\ Суддя Європейського суду з прав людини, \\ F-67075 Страсбург Cеdех, Франція, \\ e-mail:Siofra.Oleary@echr.coe.int
}

Проаналізовано сучасний стан практики ЄСПЛ щодо умов утримання в місцях позбавлення волі. Звернуто увагу на значну статистику таких справ, адже ЄСПЛ уже встановив приблизно 1300 порушень статті 3 Європейської конвенції з прав людини через умови утрамання, які вважалися нелюдськими та принизливими.

Знаковим є рішення ЄСПЛ у справі Муршич проти Хорватії, де роз'яснено стандарти Конвенції щодо наповнення тюрем. У рішенні підтверджено, що мінімальний рівень особистого простору становить $3 \mathrm{~m}^{2}$ на одну особу; пояснено, як обчислити мінімальну площу, розкрито особливості розгляду таких скарг та застосування презумпцій при вирішенні відповідних фрактичних питань.

Що стосується стандартів Європейського комітету з питань запобігання катуванням, то $€$ дві основні причини, через які Страсбурзький суд не прийняв його стандартів: (i) 3 одного боку, ЄСПЛ зобов'язаний враховувати всі відповідні обставини конкретної справи, тоді як інші міжнародні установи, як, наприклад, цей комітет, розробляють загальні стандарти у цій галузі; (ii) з іншого боку, ЄСПЛ та Комітет виконують різні ролі. Комітет бере участь у превентивних діях, спрямованих на запобігання. Суд встановлює відповідальність у судових справах за порушення в окремих справах абсолютної заборони, що міститься у статті 3.

Відповідаючи на запитання про те, як ЄСПЛ опрацював таку велику кількість заяв, що стосуються умов ув'язнення та переповненості, автор звертає увагу на пілотну процедуру судових рішень, яка розроблена в Страсбурзі з 2004 року.

Окрім того, навіть коли пілотну процедуру не застосовують, ЄСПЛ зазначає індивідуальні та загальні заходи щодо держав-відповідачів відповідно до статті 46 Конвенції.

Що ж стосується України, то на початку 2020 року ЄСПЛ розглянув справу Сукачов проти України. Порушення статей 3 та 13 було визнано одноголосно, і ЄСПЛ уважав за доцільне застосувати пілотну процедуру у цій справі. У цьому відношенні Суд наголосив на існуванні розповсюдженої структурної проблеми, що $€$ наслідком несправності української кримінально-виконавчої системи. Далі ЄСПЛ вказав на низку заходів щодо протидії цій структурній проблемі, а саме: зменшення кількості затриманих шляхом частішого використання інших запобіжних заходів, оновлення ізоляторів. Що стосується ефрективних засобів захисту, Суд закликав Україну створити незалежний орган для нагляду за ізоляторами та компенсації неадекватних умов тримання під вартою шляхом зменшення покарання відповідних ув'язнених або надання грошової компенсації.

У статті окремо розглянуто наслідки розвитку практики ЄСПЛ на правову систему ЄС. У 2016 році у знаковій справі Араньосі та Кальдарару німецький суд запитав у Суду $€ C$, чи може ймовірність неналежних умов утримання внаслідок системного дефекту у в'язницях держави-члена $Є С$, що надала запит на арешт, дозволити компетентним органам в іншій державі не видавати особу на підставі європейського ордеру на арешт. Такі ордери були видані властями Угорщини та Румунії. У цій справі Суд $Є С$ уважав, що якщо орган, відповідальний за виконання ордеру, має докази реального ризику нелюдського 
або принизливого поводження в державі-члені, де видано ордер на арешт, цей орган повинен додатково оцінити цей ризик перед прийняттям рішення про видачу особи. Ця оцінка має охоплювати питання того, чи виникає ризик зі загальних умов утримання у відповідній державі-члені (який сам собою не може призвести до відмови у виконанні ордера) та чи існують серйозні підстави вважати, що ця особа буде фрактично піддаватися такому ризику через умови, в яких передбачається її утримувати.

Ключові слова: утримання в місцях позбавлення волі, пілотна процедура, стандарти прав людини, прецедентна практика Європейського суду з прав людиню.

Стаття: надійшла до редакції 10.06.2020 прийнята до друку 12.06.2020 